\title{
THE MATURING VISION OF WALT WHITMAN'S 1871 VERSION OF DRUM-TAPS
}

\author{
AnThony Szczesiul
}

IN THE PREFACE to the 1876 two-volume Centennial Edition of Leaves of Grass, Walt Whitman writes that the entire work "revolves around the four years' war," and claims that the "Drum-Taps" cluster of Leaves is "pivotal to the rest" of the text. ${ }^{1}$ That Whitman places such an emphasis on the "Drum-Taps" section indicates how important he considered the events of the Civil War to be to his development as a poet. Interestingly, Drum-Taps exists essentially in three versions: the 1865 DrumTaps, published as a slender volume by an eager Whitman under lessthan-favorable circumstances; the "Drum-Taps" cluster of the 1871 fifth edition of Leaves of Grass, the plates of which served for the 1872 and 1876 Leaves; and the "Drum-Taps" cluster of the 1881 Leaves, from the plates of which all succeeding editions of Leaves of Grass were printed. Critical discussion of the poems of Drum-Taps has focused almost exclusively on the 1865 and 1881 versions, the 1871 version being mentioned, at most, only in passing. However, the 1871 version of the "Drum-Taps" cluster is markedly different from both the 1865 and 1881 versions. Drum-Taps moves from 53 poems in 1865, down to 32 poems in 1871 , and then back up to 43 poems in $1881 .^{2}$ But perhaps of greater significance is Whitman's drastic reorganization of the poems. A close study of the 1871 "Drum-Taps" in relation to the 1865 version reveals that the change of presentation in the 1871 version reflects a shift in Whitman's perspective of and attitude toward the American Civil War, the event he came to view as the "pivotal" point in his life as a poet. In the 1865 Drum-Taps, Whitman sees the war as being inextricably tied to his day-to-day experiences during the war years 1861-1865, whereas in the 1871 version, he looks back on the war as the major historical event of his and his nation's existence. His extensive reworking of the cluster is precipitated by his growing desire to capture and interpret the events of the war.

The larger number of poems in the 1865 version, many of which have little or no connection to the war, may easily be accounted for in light of some biographical facts. Shortly after the publication of his third edition of Leaves of Grass in 1860, Whitman was preparing a new volume of poems for the presses, tentatively titled Banner at Day-Break. 
A publisher's advertisement called the book "A Handsome Volume of about 200 Pages" and listed the following sample of titles:

Banner at Day-Break.

Washington's First Battle.

Errand-Bearers.

Pictures.

Quadrel.
The Ox-Tamer.

Poemet.

Mannahatta.

The Days.

Sonnets, \&c.\&c.\&c. ${ }^{3}$

The advertisement proved premature, for Thayer \& Eldridge went under before the volume could be brought to print. Both Gay Wilson Allen and David Goodale have stated that most of the titles listed in the advertisement later made their way into the 1865 Drum-Taps. ${ }^{4}$ Of the poems listed, Allen concludes that "Banner at Day-Break" was retitled "Song of the Banner at Day-Break," "Washington's First Battle" is "The Centenarian's Story," and "Quadrel" is "Chanting the Square Deific" (Singer, 569). Goodale argues more rigorously, and he is able to conclude reasonably that the following poems of the 1865 Drum-Taps were originally from the "Banner at Day-Break" collection: "A Farm Picture," "The Torch," "Mother and Babe," "A Broadway Pageant," and "City of Ships." Furthermore, Goodale claims that the last of these was revised after 1861 to fit the events of the war. He also states that " 'Sonnets, \&c.\&c.\&c.' may have comprised some of the shorter, unwarlike poems in Drum-Taps" such as "Beginning My Studies," "A Child's Amaze," "When I heard the Learn'd Astronomer," "Solid, Ironical, Rolling Orb," "The Ship," and so on ("Banner," 109-110).

Whitman's decision to place these poems alongside his war poems was probably rooted foremost in his eagerness to publish a volume after the five-year hiatus since the 1860 Leaves of Grass. Gay Wilson Allen describes the importance of this volume to Whitman at the time of its publication, claiming that "If he had only waited a few months longer, he might have made it a more complete reflection of the war years and his own emotional and imaginative life during the period"' (Singer, 337). Although Allen implies that the book was not wholly successful due to Whitman's impatience, Whitman considered the book to be more than satisfactory. In fact, he felt that Drum-Taps was far superior to Leaves of Grass as a formal working unit. This may seem surprising to the modern reader, for the 1865 Drum-Taps seems to have no structural unity. Decidedly domestic and peaceful poems such as "Mother and Babe," "A Farm Picture," and "A Child's Amaze" are found between poems that deal directly with the carnage and slaughter of the Civil War. But Whitman's structural intentions in this ordering of the poems may be surmised in a letter of January 6,1865 , to William D. O'Connor: 
I feel at last, \& for the first time without any demur, that I am satisfied with it - content to have it go to the world verbatim \& punctuation. It is in my opinion superior to Leaves of Grass - certainly more perfect as a work of art, being adjusted in all its proportions, $\&$ its passion having the indispensable merit that though to the ordinary reader let loose with wildest abandon, the true artist can see it is yet under control. But I am perhaps mainly satisfied with Drum-Taps because it delivers my ambition of the task that has haunted me, namely, to express in a poem . . . the pending action of this Time \& Land we swim in [Whitman's stress], with all their large conflicting fluctuations of despair \& hope, the shiftings, the masses, \& the whirl \& deafening din. . . .5

Whitman claims that the volume may seem formless on the surface, but the "true artist" will see that it is "under control." It is not unlikely that Whitman saw the volume's order of poems as having what may be termed a "montage" effect. By interspersing the war poems amid the unwarlike pieces, Whitman captures both the spirit of the "Time," the years of conflict, and the spirit of the "Land," the United States. $\mathrm{He}$ presents the reader with a vast, all-encompassing mural of life in America as the Civil War rages. For instance, as a man is awakening to a sight of corpses in the morning camp ("A Sight in Camp"), horses and cattle are feeding peacefully in a pasture ("A Farm Picture"). Or, as a northern city eagerly prepares for "red war" ("City of Ships"), a mother nestles her baby to her breast ("Mother and Babe"). In these particular instances, Whitman heightens the montage effect through the sharp, visual contrast of the side-by-side presentation of the poems on the page. Whitman usually assisted his printers in setting the type for his books, and he was obviously aware of both the thematic and physical contrasts he was creating in these instances.

The montage effect of the 1865 Drum-Taps also reflects the political frame of Whitman's mind at the time the book was published. In recent years, a number of critics increasingly have focused on the political complexities and ironies Whitman found himself facing during the Civil War. As both Betsy Erkkila and M. Wynn Thomas have argued, Whitman saw the Civil War primarily as a war to preserve the Union. ${ }^{6}$ Whitman hoped that at least the Northerners "would now at last discover true, or pure, democracy in the very process of defending it" (Thomas, 185). But as Timothy Sweet points out, the concepts of democracy and individual freedom are ironically forfeited as one enlists to defend those ideals. ${ }^{7}$ This irony is compounded by the fact that Whitman went against his earlier political principles as he "found himself on the side of national, as opposed to state, sovereignty" (Erkkila, 196). In her discussion of "Quicksand Years," Erkkila describes the poem as "a supreme moment of cultural dissonance, as the ground of Whitman's self-protective democratic faith 'gives way' under the pressure of time and the uncertain 'whirl' of history" (197). This statement may be applied not only to this single poem, but to the Drum-Taps volume as a whole. This sense of "cultural dissonance"-with all its 
complexity, irony, and resulting apprehension-is captured through the chaotic, montage ordering of the poems. As his democratic ideals were compromised and shaken, Whitman began "to experience the world as an ever-shifting quicksand of uncertainty and unmeaning" (Erkkila, 197). The ordering of the poems reflects this confusion, as no single attitude toward the war is allowed to prevail. Of all the emotional responses portrayed in the volume-hope, despair, confidence, doubtnot one is allowed to clearly emerge and carry the volume forth toward a conclusive resolution. For instance, "The Dresser," which may be seen as a turning point of resolution and acceptance in the 1871 and 1881 clusters, appears early in the 1865 volume. Furthermore, it appears before such emotionally disparate poems as "Beat! Beat! Drums!," "A March in the Ranks Hard-Prest," "A Sight in Camp," and "Year that Trembled and Reel'd Beneath Me."

Although the ordering of the poems in the 1865 Drum-Taps tends to dilute the effect of the war poetry in many instances, Whitman nonetheless felt the poems worked well together in this structuring. Perhaps he simply did not want the poems from the failed "Banner at DayBreak" collection to go unused. By integrating them into the 1865 Drum-Taps in the way that he did, he managed to find what he saw as a useful place for them. In any case, he was satisfied with the end result, despite the fact that his standards may have been compromised both by his eagerness to get a book into the hands of the public and by his desire to use the "Banner at Day-Break" poems, poems written under a burst of inspiration far different from that of the war poems.

In preparing the 1867 Leaves of Grass, Whitman annexed the 1865 Drum-Taps and Sequel to Drum-Taps by simply printing the collections from their original plates and appending them onto the back of the volume. But in 1871, Whitman stereotyped plates for a new edition of Leaves of Grass, placing the "Drum-Taps" cluster at the center of the volume and cutting the number of poems in the section down to thirty-two. Of the thirty-two remaining poems, twenty-four were from the 1865 Drum-Taps proper, six originally had appeared in Sequel to Drum-Taps 1865-1866, and one was from the 1860 Leaves of Grass. Though most of the excised poems were placed in other sections of the edition ("Marches Now the War is Over" and "Bathed in War's Perfume"), "Drum-Taps" as a unit takes on a very different character. The cluster of thirty-two war poems becomes the "pivotal" section of Leaves. Whitman himself called attention to the new significance of these poems in relation to the rest of Leaves in a line he added to "By Blue Ontario's Shore": "As a wheel turns on an axle, so I find my chant turning finally on the war." 8

Although the montage effect of the 1865 edition is lost due to the relocation of the majority of the unwarlike pieces, it has been replaced 
by what may be called a narrative sequencing of the remaining thirty-two. ${ }^{9}$ Whitman foreshadows the narrative line of development in the epigraph he added to the 1871 "Drum-Taps" cluster:

Aroused and angry,
I thought to beat the alarum, and urge relentless war;
But soon my fingers fail'd me, my face droop'd, and I resign'd myself,
To sit by the wounded and soothe them, or silently watch the dead. (261)

In the 1881 edition of Leaves of Grass, these lines are integrated into the first stanza of "The Wound-Dresser," and the 1881 "Drum-Taps" cluster consequently lacks an epigraph. But as an epigraph to the 1871 "Drum-Taps" cluster, these lines instruct the reader to approach the cluster as a narrative sequence. They suggest that the poems will follow the emotional development of the narrator as he is faced with the realities of the war. To a great extent, this is indeed the case; however, the narrator assumes a variety of personae throughout the volume, ranging from soldier to bystander to poet-figure. The real focal point of the narrative line is a representative series of emotional reactions or responses to the war; the poems progress from jingoistic idealism to doubt and reflection, and they finally move toward a reconciliation with and interpretation of the war's significance on both the personal and national level. ${ }^{10}$

In preparing the 1871 "Drum-Taps" cluster, Whitman simply extricated the war poetry from the 1865 Drum-Taps in an effort to preserve the war as history; he emphasized the historical aspect of the cluster through the new narrative sequencing. As Betsy Erkkila states, "If in the prewar period Whitman had viewed himself as a poetprophet, mythically embodying democracy and the revolutionary traditions of the past, during the war years he came to see himself as a kind of poet-historian, preserving a record of the present moment for future generations" (205). The 1871 version of the "Drum-Taps" cluster is a clear result of these shifting ambitions. Although the 1881 version of the "Drum-Taps" cluster follows roughly the same narrative pattern, the addition of eleven poems and the removal of the epigraph slows down and dilutes the effect of the narrative line. This is particularly the case near the end of the 1881 cluster, where nine poems appear after "Reconciliation" instead of four, causing the force of some of the poems to be diminished as their meanings are more widely dispersed. Therefore, the narrative line of the 1871 cluster provides us with perhaps the most crystalline perspective of Whitman's changing attitudes toward the war, and an analysis of the 1871 version reveals a number of masterful effects Whitman achieves through his reworking of the order and, in some instances, physical presentation of the poems. 
The new narrative ordering of the poems in the 1871 "DrumTaps" cluster suggests Whitman's shifting ambitions and captures his own development during the war years. Indeed, the narrator of the poems is in many instances inextricably tied to the poet-figure, and the challenge of "singing" the war becomes a primary concern in the 1871 cluster. It may be surmised that as time passed after the Civil War ended, Whitman began to experience an intense need to record the events of the war as history. Much in the same way as modern America's attitudes toward the Vietnam era have changed with passing time, Whitman began to see the Civil War simultaneously as both personal and national history, the memory of which had to be preserved. As $M$. Wynn Thomas clearly demonstrates, many of these memories were painful and devastating to Whitman, and his resulting recall of events was based on "selective memory - the kind of memory that functions as a protective device which filters out the painful elements in the original situation" (206). The result of such selective recall is that Whitman often works toward "the deeper spiritual aesthetics, rather than the surface realism, of wartime life itself" (210) ${ }^{11}$ As the war retreated into the past, Whitman gained a more coherent historical perspective of both the personal and national significance of its events. If the 1865 DrumTaps represents the chaos and confusion of "wartime life itself," the 1871 cluster represents the order and understanding which Whitman was able to cull from "the pains and obligations of memory." He hoped that his narrative representation of the war years would be true not only to his own personal memory, but to the nation's as well, for to Whitman the war was the culminating event of both personal and national history. On the personal level, the war presented Whitman's concept of comradeship, most fully articulated in the "Calamus" poems of 1860, with a real emotional outlet by way of his volunteer work in the war hospitals of Washington. On the national level, the war proved to be the testing ground of the American democratic ideal. As a result, Whitman saw in the war the potential for what could be a private, personal poetry with national significance.

As a working unit, the poems of the 1871 "Drum-Taps" may be broken down into three sections which correspond to the narrator's shifting attitudes toward the war. ${ }^{12}$ The first section, comprised of eleven poems (from "Drum-Taps" to "By the Bivouac's Fitful Flame"), serves two main purposes. It captures the jingoistic idealism which consumes both the narrator and his country in the early days of the war, and it defines the objective of the poet-figure as he sets out to sing the war. The second section contains seven poems (from "Come up from the Fields, Father" to "Year that Trembled and Reel'd Beneath Me"). It concerns itself with the realities of war which shock the narrator and fill him with reservations and doubt. Finally, in the fourteen poems of 
the third section (from "The Dresser" to "To the Leaven'd Soil They Trod"), the narrator, through his invigorated sense of comradeship, reconciles himself with the war and moves to interpret it on both a personal and national level. All of the poems of the third section exemplify the powers of comradely love and illustrate the poet-figure's regained confidence in his mission. Although these groupings are arbitrary to a certain extent, they will suffice to illustrate the emotional development of the volume. ${ }^{13}$

The first section serves as a sort of prelude or exposition to the thematic development of the cluster. The overall emotional development which takes place in the cluster will be compared to and therefore defined by its relationship to the jingoistic idealism of the narrator in the poems of this section. Appropriate to this idealism, the pervading attitude in this section of the cluster is eagerness. This eagerness is best exemplified in poems like "Drum-Taps," "1861," "Beat! Beat! Drums!" and "City of Ships" by the frequent use of imperative and exclamatory sentences. In "Beat! Beat! Drums!" for instance, the narrator supports the disruption of peace and exhorts the drums to disregard any remonstrance: "Beat! beat! drums!-Blow! bugles! Blow! / Make no parley-stop for no expostulation; / Mind not the timidmind not the weeper or prayer" (266). The drums and bugles represent the rage for war which captivates the nation. ${ }^{14}$

The second main function of the first section is to outline the role of the poet in the war. As the narrator claims in "1861," the event does not call for "dainty rhymes or sentimental love verses," but a "strong man" sounding his "sonorous voice . . . across the continent" (264). The poems "From Paumanok Starting I Fly like a Bird," "Rise, O Days, from your Fathomless Deeps" and "The Centenarian's Story" extend this concept of the war-time poet. In "From Paumonok Starting" the narrator confidently assumes the role of national poet, claiming that he will sing "to the tap of the war-drum, if need be" (266). And this confidence is echoed in the next poem, "Rise, O Days, from your Fathomless Deeps," when the speaker claims that he has had "good preparation" to chant the song of war. ${ }^{15}$

The first section closes with four poems which work together as a transitional piece between the previous idealistic poems and the succeeding realistic ones. This transitional group is accentuated by a stroke of genius on the part of Whitman. He took three short vignettes from the 1865 Drum-Taps - "Cavalry Crossing a Ford," "Bivouac on a Mountain Side," and "By the Bivouac's Fitful Flame"-and one from Sequel to Drum-Taps - "An Army Corps on the March"-and formed them into a separate, meticulously presented grouping. The new grouping of the four poems enhances their picturesque qualities; they are snapshots of everyday war scenes, not unlike the photographs of Matthew Brady 
or the paintings of Winslow Homer. ${ }^{16}$ The poems are a sort of verbal impressionism, and that Whitman intended such an effect may be seen in his striking presentation of the poems, which in the 1871 edition form four equal visual images on two facing pages (see Figure 1). This visual effect is lost in the arrangement and pagination of the 1881 edition.

The first two poems of the 1871 grouping-"An Army Corps" and "Cavalry"- are poems of motion and daylight, whereas the two "Bivouac" poems take place at night and in camp. The four as a group effectively portend the coming terror of the night to be experienced by the narrator, as night takes on characteristics which associate it with the horror and tragedy of war. The narrator will eventually move through the hellish night in "A March in the Ranks Hard-prest" and will emerge a changed man in "A Sight in Camp in the Day-break Grey and Dim." These events are foreshadowed in the "Bivouac" poems. Amid the campfires on the mountainside, the speaker makes out "The shadowy forms of men and horses, looming, large-sized, flickering" (277). The shifting light of the fires creates a "phantom" of "an occasional figure moving," and the speaker feels in the strange light that "shrubs and trees" are "stealthily watching" him (277). In "A March in the Ranks Hard-prest," the narrator will experience firsthand in this same eerie light the butchery of war.

The second section of the cluster contains seven poems (from "Come up from the Fields, Father" to "Year that Trembled and Reel'd Beneath Me") which record the narrator's initiation into the shocking reality of war. The confidence and self-assuredness seen in the first section are shaken by the harsh realities of war in the cluster's second section. The first four poems of the second section are all concerned with death in very concrete terms. For example, in "A March in the Ranks Hard-prest, and the Road Unknown," the speaker is exposed to the wholesale slaughter of war in a scene which is hauntingly reminiscent of the "Bivouac" poems. Entering a church being used as an "impromptu hospital," the speaker sees:

... a sight beyond all the pictures and poems ever made:

Shadows of deepest, deepest black, just lit by moving candles and lamps,

And by one great pitchy torch, stationary, with wild red flame, and clouds of smoke;

... (281)

As in the "Bivouac" poems, he can make out only "vaguely" the shapes in the flickering light, but the scenes of pain and death he witnesses are nonetheless horrifying. He has become a man trapped in the tragedy of war. He cannot do anything to stop it; he cannot even stop a soldier from bleeding to death. As the poem ends, the war shows itself to be unrelenting: "Resuming, marching, ever in darkness marching, on in 

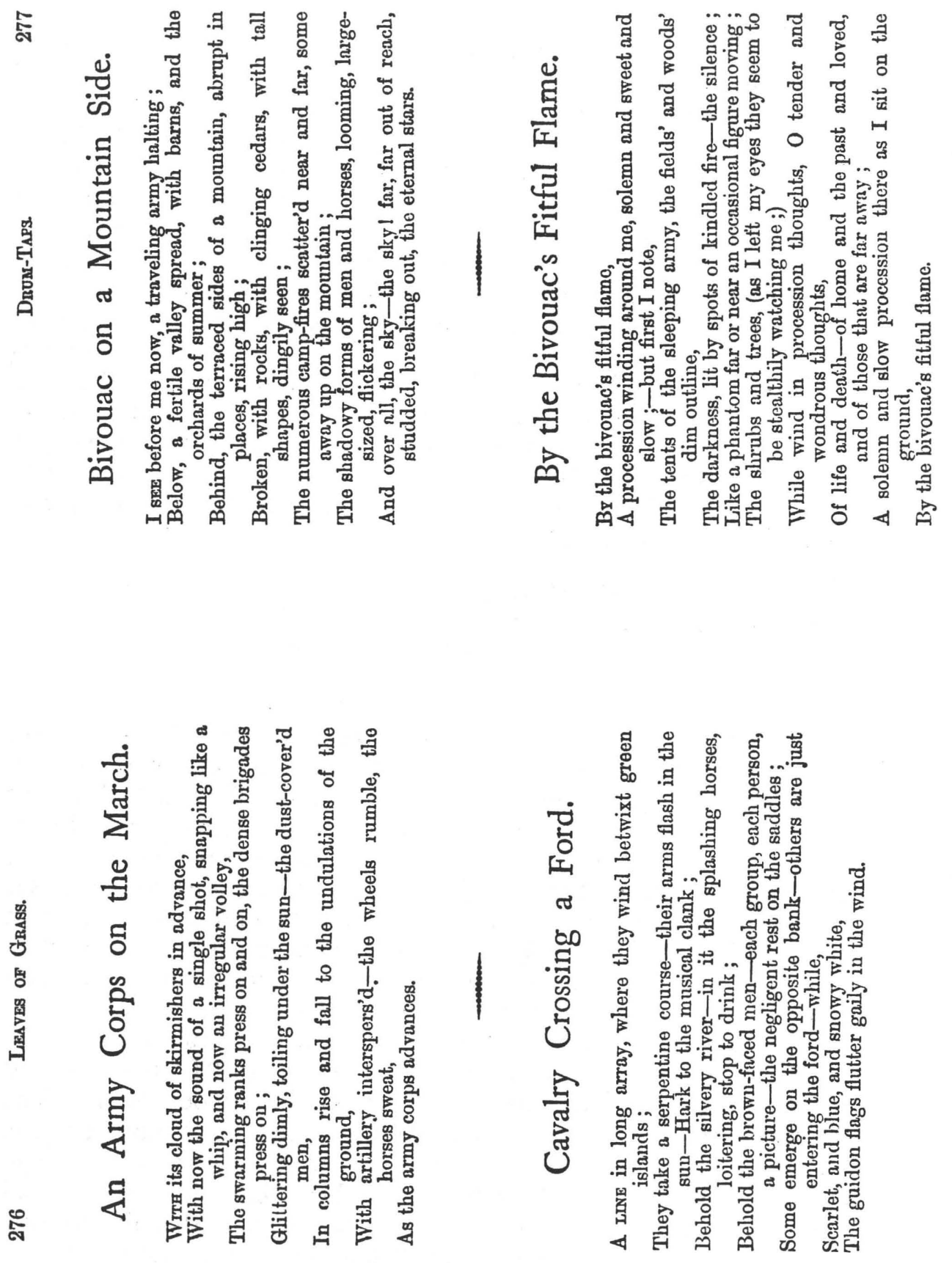

Figure 1. From "Drum-Taps," Leaves of Grass, 1871. 
the ranks,/ The unknown road still marching" (282). There is no respite to be had.

The narrator emerges from the night into the faint light of morning in "A Sight in Camp in the Day-break Grey and Dim." The vague figures from the night before become real men as the narrator encounters three dead bodies in the camp, and he identifies the face of the third body with "the face of the Christ himself" (283). The narrator sees the tragic sacrifice of war in these three faces, and the shock of this truth will send him reeling into a period of reflection and doubt.

His doubt and hesitation surfaces in the three remaining poems of the second section: "Not the Pilot," "As Toilsome I Wander'd Virginia's Woods," and "Year that Trembled and Reel'd Beneath Me." In "Not the Pilot," the poet-figure compares himself in his attempt "to compose a free march for These States" to a "weary" path-finder and "baffled" pilot (283). The real cost of war has taken its toll, and in "Year that Trembled" he questions whether or not he can continue in his earlier, idealistic manner:

A thick gloom fell through the sunshine and darken'd me; Must I change my triumphant songs? said I to myself; Must I indeed learn to chant the cold dirges of the baffled? And sullen hymns of defeat? (284)

This is the narrator's emotional low-point in the 1871 cluster. But despite his disillusionment, he has already been provided with a seed of resolution in the preceding poem, "As Toilsome I Wander'd Virginia's Woods." In this poem the narrator tells of the words he saw scrawled on an unknown soldier's grave which haunt him for years after: "Bold, cautious, true, and my loving comrade" (284). His eventual ability to see all men as his comrades, even the enemy, saves him from his present despair. His love for his fellow man helps reconcile him to the terrible cost of the war, and as the cluster progresses, the remaining poems tend to focus on the powers of love and comradeship.

In the final section of the cluster, which is comprised of the remaining fourteen poems (from "The Dresser" to "To the Leaven'd Soil They Trod"), the narrator's work with the wounded in "The Dresser" captures and inspires his spirit. He reconciles himself to the horror of war as he begins to see a new, more concrete cause being fought for: love and comradeship among his fellow man. In this final group of poems, it is no longer democracy in itself that the speaker extols; rather, it is man's love for his fellow man. The narrator comes to consider this as the seminal element of the democratic ideal. With this in mind and through close, loving contact with others, he is able to accept the cost of the war. Democracy in its abstract sense had become a hollow cause for war, but democracy as revealed through comradely love 
is worth any price. All the remaining poems add to the emotional effect of this resolution.

Though "The Dresser" is not strictly factual as an autobiographical statement-for Whitman rarely, if ever, treated patients the way the narrator of the poem does-it is autobiographically accurate from an emotional perspective. ${ }^{17}$ That Whitman came to identify himself specifically with this poem can be seen in the 1876 Centennial Edition of Leaves of Grass. In that edition the poem is placed opposite a William J. Linton engraving of Whitman, taken from a George C. Potter photograph dated circa $1871 .{ }^{18}$ The memories which remain with the narrator in "The Dresser" are not the glories of war, but the expressions of love. The poet-figure believes, as stated in "Long, too Long, O Land," that he and his country have learned from the war and its "crises of anguish," and he will try to show the world in his songs:

And now to conceive, and show to the world, what your children en-masse really are: (For who except myself has yet conceiv'd what your children en-masse really are?) (288)

An excellent example of his acceptance of the cost of war is illustrated in "Dirge for Two Veterans." The changing characteristics of the drums and the night reflect the narrator's changing attitude toward the war. In earlier poems, particularly "Drum-Taps," "Beat! Beat! Drums!" and "City of Ships," the drums had been associated with the relentless and eager call to arms that signalled the start of the war. $\mathrm{He}$ had urged them to beat forth in those poems, but now "every blow of the great convulsive drums, / Strikes me through and through" (291). As the funeral march passes, he is nonetheless able to find comfort in the scene:

O strong dead-march, you please me!

O moon immense, with your silvery face you soothe me!

O my soldiers twain! O my veterans, passing to burial!

What I have I also give you.

The moon gives you light,

And the bugles and drums give you music;

And my heart, $\mathrm{O}$ my soldiers, my veterans,

My heart gives you love. (291)

These closing stanzas of the poem tie together two primary images of the cluster's first two sections with the over-riding theme of the third. The drums had been associated in the first section with the original cry for "the red business." Likewise, the moon and the night had been associated in the second section with the terror and butchery of war. But here, the narrator's love for his comrades sanctifies the scene and endows its elements with a sense of peace. 
The climactic unifying and sanctifying act of the entire cluster is emphasized by Whitman's use of the moon and the night in "Reconciliation" and the poem which precedes it, "Look Down Fair Moon." The moon and the night are elements associated in the second section with the horror of war. Whitman accents the earlier role they had played by referring in "Reconciliation" to "the sisters Death and Night" (295). But now he sees the beauty of the night, and he asks the moon in "Look Down Fair Moon" to imbue the scenes of war with its softness:

Look down, fair moon, and bathe this scene;

Pour softly down night's nimbus floods, on faces ghastly, swollen, purple;

On the dead, on their backs, with their arms toss'd wide,

Pour down your unstinted nimbus, sacred moon. (295)

In "Reconciliation," the speaker's prophecy that men from the North and the South shall be comrades ("Over the Carnage," stanza 4) is fulfilled as he kisses a dead Confederate soldier. He refers to the Confederate as "a man divine as myself," and his reconciliation can be interpreted on both a personal and national level. On the personal level, the kiss is the final and sanctifying act of the poet during the war; his soul is now fully prepared to sing and interpret the war. On the national level, the reconciliation is symbolic of the end of the conflict and the hope for unity between North and South in the future. The poet-figure goes on in the remaining four poems to chant and interpret the war for the benefit of future generations. For instance, in "Spirit Whose Work is Done," he addresses the Spirit of the war as though it were his muse of inspiration, and asks that he may be its conduit to the future. He will sing of the kindred spirit which exists between all men and which has been strengthened by the events of the war ("How Solemn, as One by One"), and his songs, composed in the midst of the war, will be nourished by the "Northern ice and rain" and ripened by "the hot sun of the South" ("To the Leaven'd Soil They Trod") 298).

The 1871 "Drum-Taps" cluster is worthy of close inspection for a number of reasons. Just as the 1865 and 1881 versions are remarkably different and deserve to be approached individually, so too the 1871 cluster represents a unique and important development in Whitman's consciousness worthy of its own analysis. The drastic reorganization of the poems into a narrative pattern indicates Whitman's shifting attitude toward the war as it receded from his day-to-day life into the historical past. Although the 1881 version follows somewhat the same pattern as the 1871 text, the 1881 cluster lacks the epigraph which openly encourages a narrative reading. Also, though the two versions are roughly similar through the first half of the cluster, the addition of eleven poems in the 1881 version results in a different overall effect as the additional poems slow down the narrative progression. The use of the epigraph in 
the 1871 version stresses the cluster's narrative sequence, and the narrative line is made concise and powerful through the smaller number of poems. At the very least, the 1871 version of the "Drum-Taps" cluster gives the reader a glimpse of Whitman's shifting attitudes and of the growing historical perspective in which he came to view the war.

\section{University of South Carolina}

\section{NOTES}

1 Harold W. Blodgett and Sculley Bradley, eds., Leaves of Grass, Comprehensive Reader's Edition (New York: New York University Press, 1965), 750.

2 This number of 53 poems for the 1865 Drum-Taps does not include the eighteen poems of Sequel to Drum-Taps, which were appended to the volume after the death of President Lincoln.

3 David Goodale, “Walt Whitman's 'Banner at Day-Break,' 1860." Huntington Library Quarterly 26 (1962), 105; hereafter "Banner."

4 See Gay Wilson Allen, The Solitary Singer: A Critical Biography of Walt Whitman (New York: Grove Press, 1955), 267 and 569, note 25; hereafter Singer. And Goodale, 105-110.

5 Edwin Haviland Miller, ed., The Correspondence (New York: New York University Press, 1961), 1:246-247.

6 See Betsy Erkkila, Whitman the Political Poet (New York: Oxford University Press, 1989), 190-197; and M. Wynn Thomas, The Lunar Light of Whitman's Poetry (Cambridge: Harvard University Press, 1987), 178-185, for detailed discussions of Whitman's political ideals and the way the war affected them.

7 See Timothy Sweet, Traces of War: Poetry, Photography, and the Crisis of the Union (Baltimore: Johns Hopkins University Press, 1990), 14. Sweet sees Whitman's war poetry as the result of an ideological struggle to convert the reality of the war into an affirmative representation of it (see 11-45).

8 Walt Whitman, Leaves of Grass (Boston: Thayer \& Eldridge, 1871), 327. All subsequent quotations of Whitman's poetry will be from this edition.

9 A number of critics have discussed the "Drum-Taps" poems in terms of their narrative sequence, but they have focused almost exclusively on the 1881 cluster. For example, see James E. Miller, Jr., A Critical Guide to Leaves of Grass (Chicago: University of Chicago Press, 1957), 219-225; John P. McWilliams, Jr., “" 'Drum-Taps' and Battle-Pieces: The Blossom of War," American Quarterly 23 (May 1971), 181-200; and Samuel Coale, "Whitman's War: The March of a Poet," Walt Whitman Review 21 (September 1975), 85-101.

10 Although the focus of the narrative is on emotion and not specifically a single narrator, I generally will refer in my discussion of the poems to the figure of the narrator. A poem like "Come Up from the Fields, Father" obviously does not have any physical connection to "The Wound-Dresser" in a strict narrative sense, but there is an emotional one. 
11 See chapter 8, "The Pains and Obligations of Memory," of Thomas' The Lunar Light of Whitman's Poetry for an enlightening study of Whitman's shifting memories of and attitudes toward the war, 205-251.

12 The order of the 1871 "Drum-Taps" cluster runs as follows:

1) Drum-Taps (later entitled "First O Songs for a Prelude")

2) 1861

3) Beat! Beat! Drums!

4) From Paumanok Starting I Fly like a Bird

5) Rise, O Days, from your Fathomless Deeps

6) City of Ships

7) The Centenarian's Story

8) An Army Corps on the March

9) Cavalry Crossing a Ford

10) Bivouac on a Mountain Side

11) By the Bivouac's Fitful Flame

12) Come up from the Fields, Father

13) Vigil Strange I Kept on the Field one Night

14) A March in the Ranks Hard-prest, and the Road Unknown

15) A Sight in Camp in the Day-break Grey and Dim

16) Not the Pilot

17) As Toilsome I Wander'd Virginia's Woods

18) Year that Trembled and Reel'd Beneath Me

19) The Dresser (later entitled "The Wound-Dresser")

20) Long, Too Long, O Land (later entitled "Long, too Long America")

21) Give Me the Splendid Silent Sun

22) Dirge for Two Veterans

23) Over the Carnage Rose Prophetic a Voice

24) The Artilleryman's Vision

25) I Saw Old General at Bay

26) O Tan-Faced Prairie-Boy

27) Look Down Fair Moon

28) Reconciliation

29) Spirit whose Work is Done

30) How Solemn, as One by One

31) Not Youth Pertains to Me

32) To the Leaven'd Soil They Trod

13 Both John P. McWilliams, Jr. and Samuel Coale have broken the narrative sequence of the 1881 cluster down into three parts. But McWilliams sees the sequence as more of a strictly personal history as "Walt Whitman is the omnipresent and ever participating center of 'Drum Taps' " (182). It should also be noted that Coale claims that the third section of the 1881 cluster is "the hardest of the three to define" (93). This is partly due to the large number of poems Whitman added to this section of the 1881 cluster. In the 1871 cluster, the third section contains fewer poems and is consequently more clearly definable.

14 For a more detailed discussion of the political aspects of these poems of mobilization, see Thomas, 192-200.

15 See George Hutchinson, The Ecstatic Whitman: Literary Shamanism $\mathcal{E}$ the Crisis of the Union (Columbus: Ohio State University Press, 1986), 136-149. Hutchinson claims that Whitman interpreted the Civil War as a sacred ritual and argues that in some of these particular poems Whitman is adopting a "shamanistic stance" (139). 
16 See Erkkila, 213-215. But while Erkkila sees these poems as "painterly sketches" of war scenes, George Hutchinson claims that they are meant to represent the "entranced, dissociated sensibility" of a visionary (see 143-146). In either case, the visual qualities of these poems are enhanced with their presentation in the 1871 edition (see Figure 1).

17 See Agnes Dicken Cannon, "Fervid Atmosphere and Typical Events: Autobiography in Drum-Taps," Walt Whitman Review 20 (September 1974), 79-96, for a discussion of autobiographical aspects in the "Drum-Taps" poetry.

18 See Ed Folsom, “' 'This Heart's Geography's Map': The Photographs of Walt Whitman," Walt Whitman Quarterly Review 4 (1986-1987), 49-50. This engraving was also used in Memoranda During the War, 1875-76. 